\title{
Alat Permainan Edukatif: Analisis Pengembangan Literasi Sains Anak Usia Dini
}

\author{
Jeni Roes Widayati ${ }^{\circledR}$, Rien Safrina ${ }^{2}$, Yetti Supriyati ${ }^{3}$ \\ Pendidikan Anak Usia Dini, Universitas Negeri Jakarta \\ DOI: $10.31004 /$ obsesi.v5i1.692
}

\begin{abstract}
Abstrak
Tujuan penelitian untuk mengetahui dan mendeskripsikan konsep sains, proses sains, dan bentuk aplikatif sains anak usia dini yang diperoleh setelah menggunakan alat permainan edukatif di PP IPTEK TMII. Metode yang digunakan dalam penelitian ini adalah metode analisis konten dengan pendekatan kualitatif. Hasil penelitian menunjukkan bahwa konsep literasi dari alat permainan edukatif di PP IPTEK TMII adalah memperkenalkan berbagai bentuk pengetahuan sains sederhana pada anak usia dini. Proses literasi sains pada alat permainan edukatif di PP IPTEK TMII adalah pemandu mendamping, mengawasi, mengamati, serta memberikan contoh penggunaannya. Bentuk aplikatif alat permainan edukatif yaitu terdapat anak yang berhasil menghasilkan suara serta bunyi yang berirama melalui musik pipa, musik dapur, musik lantai dan musik kayu sehingga alat permainan edukatif tersebut dapat mengembangkan literasi anak. Untuk itu, alat permainan edukatif anak usia dini merupakan alat yang dirancang untuk mengembangkan aspek perkembangan anak salah satunya pengembangan literasi sains.
\end{abstract}

Kata Kunci: sains; literasi; alat permainan edukatif

\begin{abstract}
The purpose of this research is to find out and describe the concepts of science, science processes, and applicative forms of early childhood science obtained after using educational play tools in PP TMII Science and Technology. The method used in this research is content analysis method with a qualitative approach. The results showed that the concept of literacy from an educational game tool in PP IPTEK TMII was to introduce various forms of simple science knowledge to young children. The process of scientific literacy in educational game tools in PP IPTEK TMII is a guide to assist, supervise, observe, and give examples of their use. The applicative form of educational game tools is that there are children who are able to produce rhythmic sounds and sounds through pipe music, kitchen music, floor music and wooden music so that the educational play tool can develop children's literacy. For this reason, early childhood educational game tools are tools designed to develop aspects of child development, one of which is the development of scientific literacy.
\end{abstract}

Keywords: science; literacy; educational games.

Copyright (c) 2020 Jeni Roes Widayati, Rien Safrina, Yetti Supriyati

$\triangle$ Corresponding author :

Email Address : jeniroes3@gmail.com (Jakarta, Indonesia)

Received 30 July 2020, Accepted 4 August 2020, Published 5 August 2020 


\section{PENDAHULUAN}

Potensi anak usia dini dapat dioptimalkan dalam berbagai kemampuan adalah harapan yang harus diwujudkan baik oleh setiap orang tua, guru, lembaga, atau pemerintah (Kurniah et al., 2019). Mendidik anak sejak usia dini merupakan tugas serta prioritas utama bagi setiap orang tua, guru, lembaga atau pemerintah. Memaksimalkan pendidikan anak usia dini harus mengintegrasikan seluruh aspek lingkungan anak yang memiliki visi serta misi yang dalam memberikan layanan pendidikan.

Menurut Black et al (2017), menyatakan bahwa kebijakan dan program anak usia dini yang adil sangat penting untuk memenuhi tujuan pembangunan berkelanjutan, dan bagi anak-anak untuk mengembangkan keterampilan intelektual, kreativitas, dan kesejahteraan yang diperlukan untuk menjadi orang dewasa yang sehat dan produktif. Pendidikan anak usia dini merupakan pondasi dasar bagi perkembangan sikap dan perilaku manusia serta berpengaruh terhadap kualitas SDM bagi setiap bangsa. Pembangunan sumber daya manusia yang baik diawali dengan pembangunan kualitas layanan Pendidikan Anak Usia Dini (PAUD) yang baik juga. Sintesa anak usia dini merupakan sosok individu yang berada pada periode usia lahir hingga delapan tahun yang mengalami periode perkembangan pesat, memiliki potensi untuk belajar lebih cepat didukung oleh percepatan kapasitas otak, serta memiliki karateristik yang unik (Ayuni \& Setiawati, 2019; Roza et al., 2020).

Anak usia dini adalah periode perkembangan yang sangat sensitif terhadap kondisi lingkungan yang dipengaruhi oleh pendapatan keluarga dan program-program awal pengembangan dapat mencapai usia dewasa (Ristikari et al., 2018). Anak usia dini memiliki makna sebagai individu yang unik di mana pola pertumbuhan dan perkembangan aspek fisik, kognitif, sosioemosional, kreativitas, bahasa dan komunikasi berkembang secara khusus dan sesuai dengan tahapannya masing-masing (Pebriana, 2017)

Literasi sains memiliki sifat multidimensi yang mencakup kemampuan untuk membaca serta merespons secara kritis berbagai bentuk laporan berita dengan komponen sains (McClune, 2017). Berliterasi sains sama halnya dengan melatih individu untuk memiliki pola pikir yang responsif dan kritis terhadap berbagai bentuk konten bacaan sebelum dikomunikasikan ke orang lain, hal ini berarti setiap orang yang kritis memiliki kemampuan literasi sains yang baik. Keterampilan ini dibutuhkan anak untuk meraih prestasi maksimal di lingkungan sekolah. Siswa yang memiliki literasi sains adalah siswa yang mampu menerapkan pengetahuannya untuk memecahkan setiap masalah yang dihadapi sesuai dengan konteksnya (Stone \& Conrad, 2017). Setiap masalah yang dihadapi tentunya berkaitan dengan penyelesaian tugas-tugas sekolah baik ditinjau dalam aspek akademik maupun aspek moral. Anak yang memiliki kemampuan literasi sains yang baik memiliki kemampuan berpikir yang kritis dan solutif. Penelitian Rahayuni menunjukkan bahwa terdapat hubungan positif yang cukup kuat antara keterampilan berpikir kritis dan literasi sains (Rahayuni, 2016).

Literasi sains sebagai salah satu literasi dasar yang sangat penting bagi peserta didik, orang tua, dan seluruh warga masyarakat. Hal ini disepakati oleh World Economic Forum pada tahun 2015 sebagai prasyarat kecakapan hidup di abad ke-21 yang dapat dikembangkan melalui pendidikan yang terintergrasi, mulai dari keluarga, sekolah, sampai dengan masyarakat (Pendidikan Kebudayaan, 2017). Pendidikan sains sebagai pendidikan yang secara umum bertanggung jawab dan berperan penting dalam menghasilkan dan membentuk peserta didik dalam memiliki kemampuan berpikir kritis, logis, kreatif, inovatif, dan berdaya saing global (Abidin \& Mulyati, 2017).

Urgensi literasi sains di dunia pendidikan digunakan sebagai alat untuk mengukur komponen materi sains yang meliputi; pengetahuan konten sains, pengetahuan sains sebagai cara untuk mengetahui, pemahaman dan implementasi penyelidikan ilmiah (Britton \& Schneider, 2014). Secara konsep literasi sains merupakan bagian dari implementasi kontenkonten sains, sehingga untuk mengukur kemampuan anak dibidang sains dapat dilihat dari penerapan literasi sains anak. Secara teknis hal ini dapat dilakukan dengan melihat 
kemampuan berbicara, menulis, hingga sikap siswa sepanjang melakukan kegiatan belajar sains di sekolah.

Menurut Gropen et al, (2017), bahwa guru dapat mendukung perkembangan konseptual anak dengan memberikannya kesempatan untuk membuat prediksi dan merevisi ide-ide mereka berdasarkan bukti dari kegiatan eksplorasinya. Literasi sains membuat orang lebih bijak dalam merespons dan membuat keputusan mengenai masalah yang belum terbukti benar (Ristina et al., 2019). Literasi sains mendorong individu menerapkan pengetahuan sainsnya melalui bentuk sikap, perilaku, serta cara berpikir yang konkrit. Sumber lain menambahkan bahwa kerangka literasi ilmiah mencakup penilaian yang meliputi aspekaspek metakognisi, keterampilan pemecahan masalah untuk kehidupannya, dan konteks global untuk masalah ilmiah (Avargil et al., 2017).

Berdasarkan pendapat di atas bahwa keterampilan literasi sains merupakan kemampuan dalam mengontrol ranah atau proses kognitif dan kemampuan individu dalam memecahkan masalah peribadi hingga sosial secara ilmiah. Sintesa literasi sains merupakan keterampilan dalam mengimplementasikan sains yang mencakup beberapa kemampuan yaitu; 1) pengetahuan terhadap konten sains 2) penguasaan terhadap proses sains, dan 3) pengaplikasian terhadap sains.

Keterampilan literasi sains pada anak dapat distimulasi dengan alat permainan edukatif, karena alat permainan edukatif dapat membantu mengembangkan aspek-aspek perkembangan anak. Hak ini sependapat dengan (Ndeot et al., 2019) bahwa alat permainan edukatif merupakan alat yang sengaja dirancang secara khusus untuk mengembangkan aspek perkembangan anak. Artinya, alat permainan edukatif merupakan alat permainan yang dirancang untuk kebutuhan pembelajaran anak usia dini.

Menurut Negara \& Darmawati (2017), bahwa Alat Permainan Edukatif (APE) adalah alat permainan yang dapat memberikan fungsi permainan secara optimal dalam perkembangan anak, melalui permainan ini anak akan selalu dapat mengembangkan kemampuan fisik, bahasa, kognitif dan adaptasi sosialnya. Kegiatan bermain anak usia dini dilakukan dengan menggunakan alat permainan edukatif. Penggunaan alat permainan edukatif anak dapat mengembangkan aspek-aspek perkembangannya. Artinya alat permainan edukatif merupakan semua alat permainan yang memiliki nilai edukasi bagi anak usia dini.

Alat permainan edukatif adalah salah satu media berbasis simulasi yang didesain untuk menstimulasikan permasalahan yang ada, sehingga diperoleh esensi ilmu yang dapat digunakan untuk menyelesaikan masalah (Indriasih, 2015). Tugas perkembangan anak usia dini dapat dicapai melalui kegiatan bermain dengan menggunakan alat permainan edukatif. Alat permainan edukatif merupakan alat yang digunakan oleh anak usia dini untuk memenuhi tugas perkembangannya dengan cara bermain. Hal ini dipertegas dalam sumber lain yang menyatakan bahwa alat permainan edukatif adalah alat permainan yang sengaja dirancang khusus untuk kepentingan pendidikan (Hendayani, 2012). Sintesa alat permainan edukatif merupakan segala bentuk alat permainan yang digunakan anak untuk memenuhi tugas perkembangannya dengan cara bermain. Melalui penggunaan alat permainan edukatif, anak dapat mengembangkan aspek-aspek perkembangannya secara aktif. Teknik penggunaan alat permainan edukatif dirancang dengan menyesuaikan tujuan pengembangan yang telah ditetapkan sebelumnya.

Hasil penelitian Vahey et al., (2018), menunjukkan bahwa, kegiatan literasi sains dapat diberikan sedini mungkin pada anak melalui berbagai macam metode. Pengembangan keterampilan literasi sains dirumah dapat dilakukan dengan menggunakan metode diskusi antara orang tua dan anak mengenai konten bacaan yang memuat materi sains. Konten bacaan materi sains, para orang tua dapat mengajak anak untuk berdiskusi dengan cara mendorongnya untuk bertanya, menjawab serta mengutarakan alasan-alasan pertanyaan dan jawaban sebagaimana konten sains materi tersebut. Hal ini melatih anak untuk mengimajinasikan pesan-pesan apa yang diterima serta pesan-pesan apa yang akan 
dikomunikasikan. Hasil penelitian Yamin, Permanasari, Redjeki, dan Sopandi (2019) menunjukkan bahwa, kemampuan literasi sains anak dapat dikembangkan melalui pengalaman langsung selama belajar sains. Pengalaman yang diperoleh pada saat mengamati, mengeksplorasi dan bereksperimen, anak akan lebih memaknai pengetahuan yang telah didapatkannya selama proses pembelajaran.

Berdasarkan penjelasan di atas, maka kebaruan penelitian ini adalah mengenai konsep sains, proses sains, dan bentuk aplikatif sains pada anak usia dini. Fokus penelitian mengenai pengembangan literasi sains anak usia dini melalui penggunaan alat permainan edukatif di PP IPTEK TMII. Subfokus penelitian yaitu; konsep sains, proses sains, dan bentuk aplikatif sains pada anak usia dini selama menggunakan alat permainan edukatif di PP IPTEK TMII. Rumusan masalah dalam penelitian adalah bagaimana terbentuknya konsep sains anak usia dini yang diperoleh setelah menggunakan alat permainan edukatif di PP IPTEK TMII ?, bagaimana proses sains yang dilakukan anak usia dini selama menggunakan alat permainan edukatif tersebut di PP IPTEK TMII?, dan agaimana bentuk aplikatif sains pada anak usia dini selama menggunakan alat permainan edukatif di PP IPTEK TMII ?.

\section{METODOLOGI}

Metode yang digunakan dalam penelitian ini adalah metode analisis konten dengan pendekatan kualitatif. Penelitian dilaksanakan pada bulan Desember 2019 sampai Mei 2020. Kerangka metodologis dan pendekatan ini digunakan untuk mengkaji fokus penelitian yaitu pengembangan literasi sains melalui penggunaan alat permainan edukatif di PP-IPTEK Jakarta seperti: APE Telepon Pipa, APE Pipa Musik, APE Musik Dapur, APE Papan Gelinding, APE Katrol, APE Bola Berpacu, APE Parabola Berbisik, APE Mesin Putar. Berikut ini gambar enam tahapan prosedur penelitian yang dilakukan peneliti.

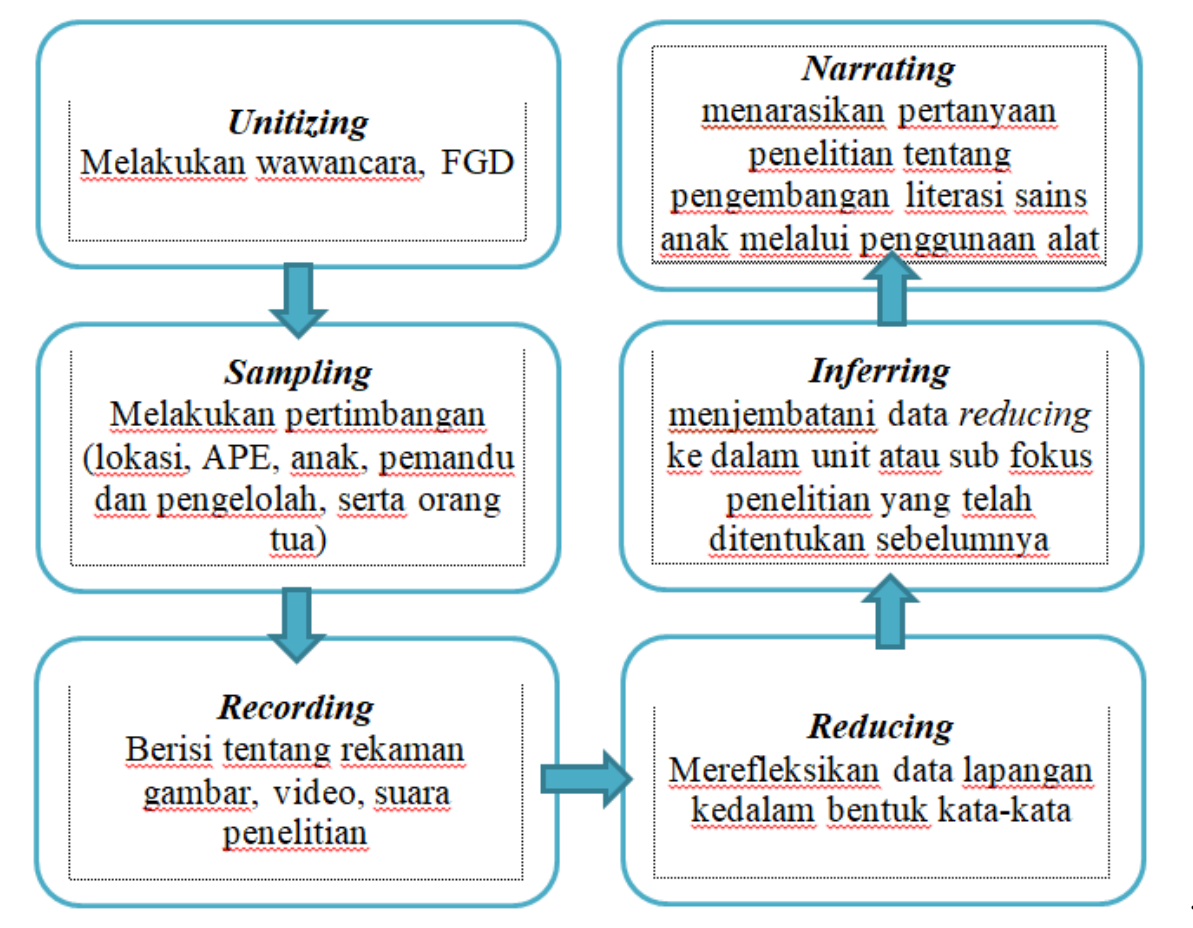

Gambar 1. Enam Tahap Penelitian (Krippendorff, 2004)

Data-data yang dinarasikan merupakan data mentah yang diambil dari sampel penelitian. Data tersebut diambil dengan menggunakan teknik pengumpulan data observasi, wawancara, angket atau kuesioner dan dokumentasi. 
Tabel 1. Lembar observasi pengembangan literasi sains anak usia dini melalui penggunaan alat permainan edukatif di PP IPTEK TMII Jakarta

\begin{tabular}{cll}
\hline No. & \multicolumn{1}{c}{ Pengamatan } & Catatan \\
\hline 1 & Pemandu mendampingi anak selama menggunakan APE. & \\
\hline 2 & Teknis pendampingan yang dilakukan oleh pemandu saat menggunakan APE. & \\
\hline 3 & APE yang sering digunakan oleh anak usia dini. \\
\hline 4 & Teknis situasi yang biasanya dilakukan anak ketika menggunakan APE. \\
\hline 5 & Hasil karya yang biasanya anak-anak buat melalui APE. & \\
\hline 6 & Conten materi sains yang biasanya disampaikan pemandu melalui APE.
\end{tabular}

Tabel 2. Lembar observasi pengembangan literasi sains anak usia dini melalui penggunaan alat permainan edukatif di Taman Bermain Jakarta

\begin{tabular}{cll}
\hline No. & \multicolumn{1}{c}{ Pengamatan } & Catatan \\
\hline 1 & Alat yang tersedia di Taman Bermain. & \\
\hline 2 & Usia anak yang datang ke Taman Bermain. \\
\hline 3 & Jarak tempat tinggal anak yang datang ke Taman Bermain. \\
\hline 4 & Alat bermain yang digunakan anak di Taman Bermain. \\
\hline 5 & $\begin{array}{l}\text { Ibu yang mendampingi anak saat bermain dengan menggunakan alat } \\
\text { bermain di Taman Bermain. }\end{array}$ \\
\hline 6 & Anak sudah tahu cara menggunakan alat-alat bermain di Taman Bermain. \\
\hline 7 & Cara mendampingi anak saat menggunakan alat bermain di Taman Bermain. \\
\hline 8 & Ibu mengetahui manfaat alat permainan di Taman Bermain. \\
\hline 10 & Alat-alat bermain di Taman Bermain dapat mengajarkan sains kepada anak. \\
\hline & $\begin{array}{l}\text { Cara Ibu mengajarkan sains kepada anak dengan menggunakan alat } \\
\text { bermain di Taman Bermain. }\end{array}$ \\
\hline
\end{tabular}

Tabel 3 Wawancara umum di PP IPTEKS TMII

\begin{tabular}{|c|c|c|}
\hline No. & $\begin{array}{l}\text { Pertanyaan } \\
\end{array}$ & Jawaban \\
\hline 1 & $\begin{array}{l}\text { Alat permainan edukatif apa saja yang sering digunakan } \\
\text { anak usia dini di PP IPTEKS TMII ini ? }\end{array}$ & \\
\hline 2 & $\begin{array}{l}\text { Mengapa Alat Permainan Edukatif tersebut sering } \\
\text { digunakan oleh anak usia dini ? }\end{array}$ & \\
\hline 3 & $\begin{array}{l}\text { Apakah pemandu selalu mendampingi kegiatan anak } \\
\text { dalam menggunakan APE tersebut? }\end{array}$ & \\
\hline 4 & $\begin{array}{l}\text { Bagaimana teknis pendampingan yang dilakukan } \\
\text { pemandu ketika mendampingi anak dalam menggunakan } \\
\text { APE tersebut? }\end{array}$ & \\
\hline
\end{tabular}

Hasil penelitian disederhanakan dan dianalisa lebih dalam dengan menggunakan definisi konseptual dari susunan teori substansif. Pemeriksaan keabsahan data dilakukan melalui uji derajat kepercayaan (credibility), keteralihan (transferability), kebergantungan (dependendability), dan kepastian (comfirmability).

\section{HASIL DAN PEMBAHASAN}

Hasil Analisis Pengembangan Literasi Sains Anak Usia Dini melalui Penggunaan Alat Permainan Edukatif di PP IPTEKS TMII Jakarta Timur

Berdasarkan observasi umum, APE di IPTEKS TMII Jakarta Timur memiliki beberapa arena yaitu explorasi, peneliti cilik, wahana mekanika, dan di luar gedung PP IPTEK. Antara lain sebagai berikut: Alat permainan edukatif telpon pipa (arena explorasi), alat permainan edukatif pipa musik (arena peneliti cilik), alat permainan edukatif musik dapur (arena peneliti cilik), alat permainan edukatif papan gelinding (arena explorasi), alat permainan edukatif katrol (wahana mekanika), alat permainan edukatif bola berpacu (wahana mekanika), alat permainan edukatif parabola berisik (di luar gedung PP IPTEK), alat permainan edukatif mesin berputar (wahana mekanika). 
Pemandu selalu mendampingi kegiatan anak dalam menggunakan APE agar anakanak yang datang di lokasi ini dapat memainkan setiap APE secara bergiliran. Tetapi pemandu tidak langsung menghampiri anak melainkan mengawasi dari jarak yang cukup dekat, dan akan menghampiri anak apabila anak tidak paham atau tidak sesuai prosedur dalam memainkan APE, atau bersikap yang akan membahayakan dirinya atau akan merusak APE. Pada saat kondisi yang memungkinkan, pemandu sebisa mungkin mendekati anak untuk memberikan pengetahuan konten sain yang terkandung dalam APE dan manfaat APE dalam kehidupan sehari-hari.

Pemandu mengawasi dari jarak yang cukup dekat dan menghampiri anak yang sedang memainkan APE. Pemandu mengamati anak terlebih dahulu dalam menggunakan alat peraga, apabila anak belum sesuai dengan prosedur atau standar dalam menggunakan alat peraga, pemandu memberikan contoh sesuai dengan standar atau prosedur. Pemandu langsung mencontohkan bagaimana alat peraga tersebut digunakan sesuai dengan standar, memotivasi anak untuk bertanya dan mengeksplorasi APE sehingga anak menemukan jawaban atas pertanyaannya selain itu pemandu juga memberikan contoh-contoh implementasi APE dalam kehidupan sehari-hari. Pemandu melakukan pendampingan kegiatan bermain anak menggunakan APE tersebut hingga selesai atau sudah tidak ada pertanyaan lagi.

Pada umumnya anak-anak menyukai hampir semua APE baik yang terdapat di Arena Peneliti Cilik (APC) maupun di Arena Eksplorasi. Hal ini terlihat hampir setiap anak mencoba semua APE di arena ini. Tetapi mereka tidak bisa berlama-lama mencobanya selain karena berbatas waktu dimana harus bergantian dengan yang lain, tetapi juga karena keinginanya untuk segera mencoba APE yang lain.

Dalam memainkan musik pipa maupun musik dapur juga musik lantai dan musik kayu, terdapat anak yang berhasil mengasilan suara atau bunyi yang berirama. Anak dapat membuat berbagai bentuk benda misalnya pipa telepon, anak dapat menemukan sumber suara dan keluarnya suara, serta anak dapat menyimpulkan sumber suara yang sama. Anak menemukan warna pipa harus sama saat bermain telepon pipa untuk dapat berkomunikasi dengan lawan bicaranya.

Mengenalkan berbagai bentuk pengetahuan sains sederhana melalui APE yang terdapat di PP IPTEK TMII kepada anak-anak, misalnya konsep bidang miring, gravitasi, gelombang bunyi, pesawat sederhana, katrol dan lainnya. Konten sains diberikan kepada anak dengan cara pemandu mendampingi anak dalam memainkan APE, menanyakan fenomena apa yang dirasakan anak, mengapa demikian, dan memprediksi apa yang akan terjadi serta memberikan kesempatan anak untuk melakukan imbal balik atau bertanya serta pemandu menyampaikan bentuk aplikatif atau implementasi APE dalam kehidupan seharihari.

\section{Hasil wawancara dalam pengembangan literasi sains anak usia dini melalui penggunaan alat permainan edukatif di PP IPTEKS TMII Jakarta Timur}

Berdasarkan hasil wawancara yang dilakukan bahwa sebenarnya hampir semua APE di sini disukai anak-anak. Mereka mencoba semuanya, hanya saja ada anak yang hanya sekilas mencobanya entah karena keterbatasan waktu (karena mereka kesini pada umumnya dengan rombongan), atau karena konsentrasi anak-anak yang masih pendek. Sehingga melaihat banyaknya permainan di sini, anak ingin mencoba semuanya. APE yang sering digunakan anak di ruangan area peneliti cilik adalah labirin tak terhingga, musik pipa, piano lantai, puzzle, musik dapur. Sedangkan di area eksplorasi PAUD adalah lego, panjat tebing mini dan telephone pipa.

Selain itu anak-anak juga menyukai APE yang sebenarnya diperuntukkan anak usia diatas 8 tahun misalnya mesin putar, bola berpacu, katrol yang terletak di wahana mekanika dan berjabat tangan yang terletak di wahana optik. Alat permainan edukatif yang diperuntukkan bagi anak usia dini di PP IPTEKS TMII ditempatkan di dua arena yaitu arena 
peneliti cilik dan arena eksplorasi tetapi anak-anak juga menyukai alat permainan edukatif yang terletak di arena atau wahana lainnya. Hampir semua APE di kedua tempat tersebut disukai oleh anak-anak, selain itu anak-anak juga menyukai di wahana lain yaitu di wahana mekanika yaitu katrol, bola berpacu dan mesin putar dan wahana optik misalnya APE berjabat tangan.

Hasil wawancara yag dilakukan pada pemandu mengenia pendampingan/pemandu anak dalam mengggunakan APE adalah "Ya, khususnya di arena peneliti cilik dan arena eksplorasi ditempatkan satu orang pemandu. Pendampingan selain ditujukan agar anak dapat menggunakan APE sesuai dengan standar serta memahami konsep APE dan implementasinya dalam kehidupan sehari-hari, selain juga untuk menghindari kekhawatiran terjadi kecelakaan pada anak saat sedang bermain juga untuk menghindari kerusakan pada APE. Tidak, untuk APE seperti APE jenis puzzle, pipa musik, pengenal waktu, musik kayu, balok, komputer pengenal hewan (melalui suara), dan silsilah keluarga. Alasan; aman digunakan untuk anak dan dapat digunakan secara mandiri oleh mereka. Meski demikian, namun apabila jenis APE ini digunakan tidak sebagaimana mestinya maka akan dilakukan pendampingan terhadap anak-anak yang menggunakan APE tersebut". Pemandu tersebut menjelaskan bahwa teknis yang dilakukan dalam mendamping anak adalah Pertama, pemandu mengenalkan APE atau alat peraga yang akan digunakan oleh anak. Kedua, pemandu mencontohkan bagaimana alat peraga tersebut digunakan sesuai dengan standar. Ketiga, pemandu melakukan pendampingan kegiatan bermain anak menggunakan APE tersebut hingga selesai. Teknis cara memandu seperti ini hanya digunakan khusus bagi orang tua yang kritis atau sering bertanya-tanya, sehingga untuk meminimalisir waktu maka para pemandu menjelaskan teknis penggunaan alat permainan tersebut. Hal ini dilakukan agar anak-anak yang datang di lokasi ini dapat memainkan setiap APE secara bergiliran dan dapat memainkannya sesuai dengan standar.

Berdasarkan hasil pengembangan literasi sains anak usia dini konsep sains melalui penggunaan alat permainan edukatif di PP IPTEKS TMII Jakarta Timur adalah alat permainan edukatif telepon pipa, dapat membentuk konsep sains bunyi. Anak dapat mendengarkan bunyi dan mengenali sumber bunyi. Diperuntukkan untuk anak usia dua hingga lima tahun. Alat permainan edukatif papan gelinding atau dorong gelinding, dapat membentuk konsep sains berupa bidang miring. Anak dapat mengamati pergerakan bola dari permukaan yang lebih tinggi ke permukaan yang lebih rendah. Diperuntukan bagi anak usia dua sampai lima tahun. Alat permainan edukatif musik pipa, dapat membentuk konsep sains bunyi. Anak dapat mengenali perbedaan bunyi yang dihasilkan dari panjang pipa yang berbeda-beda. Diperuntukan bagi anak usia dua sampai delapan tahun. Alat permainan edukatif musik dapur, dapat membentuk konsep sains bunyi. Proses sains yang terjadi adalah anak dapat mengamati perbedaan bunyi yang dihasilkan oleh berbagai bahan. Anak mengenali suara yang dihasilkan oleh benda yang dipukul. Diperuntukan bagi anak usia dua sampai delapan tahun. Alat permainan edukatif bola berpacu, dapat membentuk konsep sains bidang miring. Anak dapat mengamati perbedaan pergerakan bola dari permukaan tertinggi ke permukaan terendah. Diperuntukan bagi anak usia tujuh tahun sampai dewasa.

Alat permainan edukatif mesin berputar, dapat membentuk konsep sains gerak berputar pada poros atau sumbunya. Anak dapat mengamati perbedaan kecepatan putaran. Diperuntukan bagi anak usia tujuh tahun sampai dewasa. Alat permainan edukatif katrol, dapat membentuk konsep sains pesawat sederhana. Anak dapat mengamati perbedaan kemudahan dalam memindahkan benda. Diperuntukan bagi anak usia tujuh tahun sampai dewasa. Alat permainan edukatif ayunan, dapat membentuk konsep sains ayunan bandul. Anak dapat menggerakan ayunan dengan menjaga keseimbangan. Diperuntukan bagi anak usia dua sampai delapan tahun. Alat permainan edukatif perosotan, dapat membentuk konsep sains bidang miring dan gesekan. Anak dapat mengenali kegiatan meluncur yang dilakukan dari atas ke bawah. Diperuntukan bagi anak usia dua sampai delapan tahun. Alat permainan edukatif jungkat-jungkit, dapat membentuk konsep sains keseimbangan. Anak 
dapat mengenali beban dan keseimbangan. Diperuntukan bagi anak usia dua sampai delapan tahun. Alat permainan edukatif ayunan, dapat membentuk konsep sains ayunan bandul. Anak dapat menggerakan kuda-kudaan dengan menjaga keseimbangan. Diperuntukan bagi anak usia dua sampai delapan tahun.

\section{Hasil Dokumentasi Pengembangan Literasi Sains Anak Usia Dini melalui Penggunaan Alat Permainan Edukatif di PP IPTEK TMII}

Gedung Pusat Peragaan Ilmu Pengetahuan dan Teknologi Taman Mini Indonesia Indah (TMII) Jakarta Timur. Gedung PP IPTEKS TMII beralamat di Jalan Raya TMII, RW.10, Ceger, Kec. Cipayung, Kota Jakarta Timur, Daerah Khusus Ibukota Jakarta 13810. PP-IPTEK memiliki sarana berupa gedung yang di desain futuristik dengan luas lantai $23.400 \mathrm{~m}^{2}$. Saat ini sekitar 300 alat peraga tersebar di gallery yang terbagi dalam 14 wahana, dan didukung oleh bengkel atau workshop yang cukup lengkap untuk pembuatan prototype dan manufaktur alat peraga, antara lain : elektronik, kayu dan bubut. Halaman seluas $42.300 \mathrm{~m}^{2}$ sangat memadai untuk berbagai kegiatan out-door, science camp, dan parkir bagi rombongan berjumlah besar.

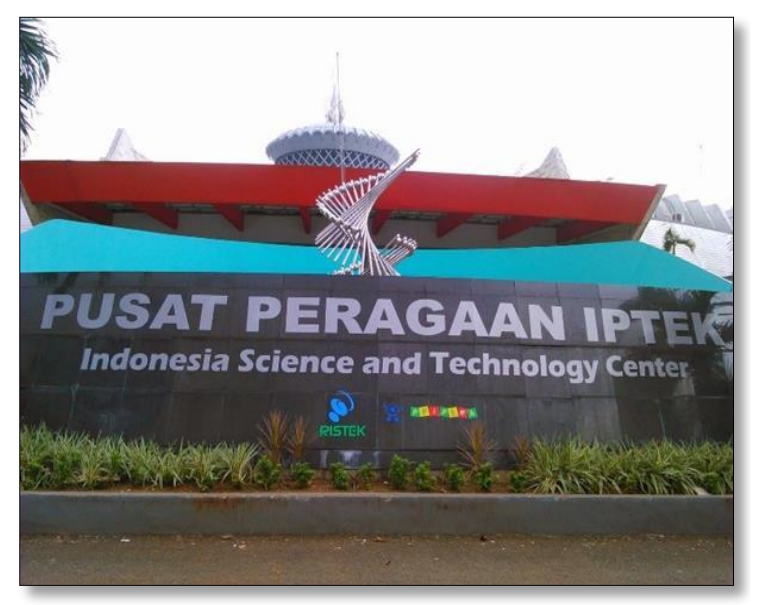

Gambar 2. PP IPTEKS TMII Jakarta Timur

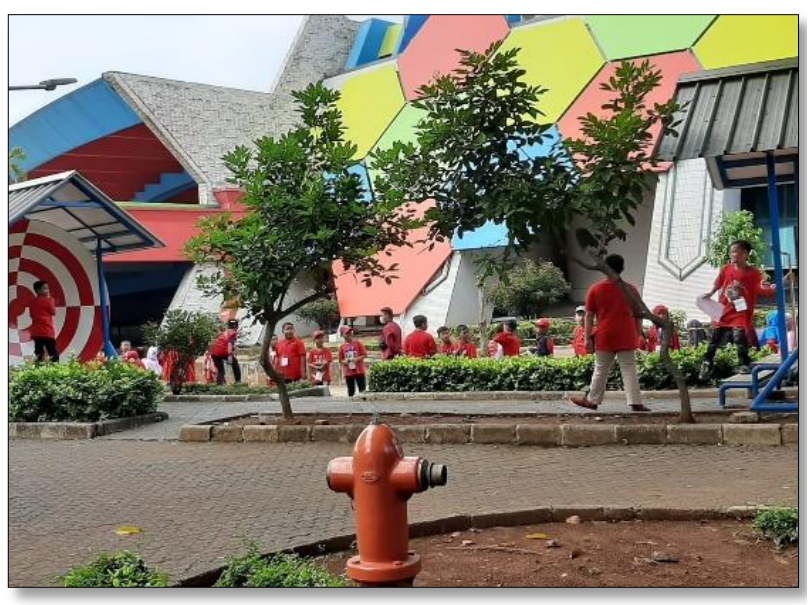

Gambar 3. Gedung PP IPTEKS TMII Jakarta Timur

Penulis sedang melakukan wawancara dengan beberapa pemandu di PP-IPTEK TMII. mengenai bentuk pengetahuan sains, proses sains, dan bentuk aplikatif sains pada anak usia dini mengenai alat permainan edukatif (APE).
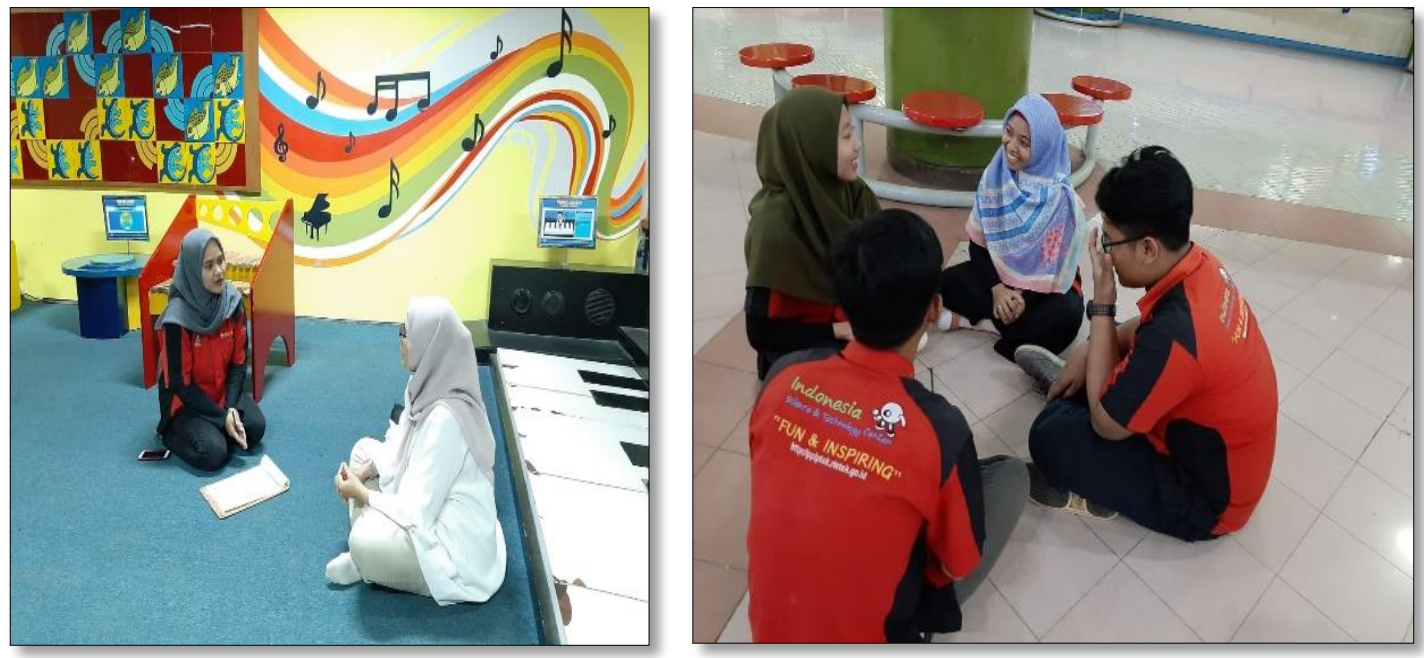

Gambar 4. Penulis sedang Wawancara dengan Beberapa Pemandu di PP-IPTEK TMII 


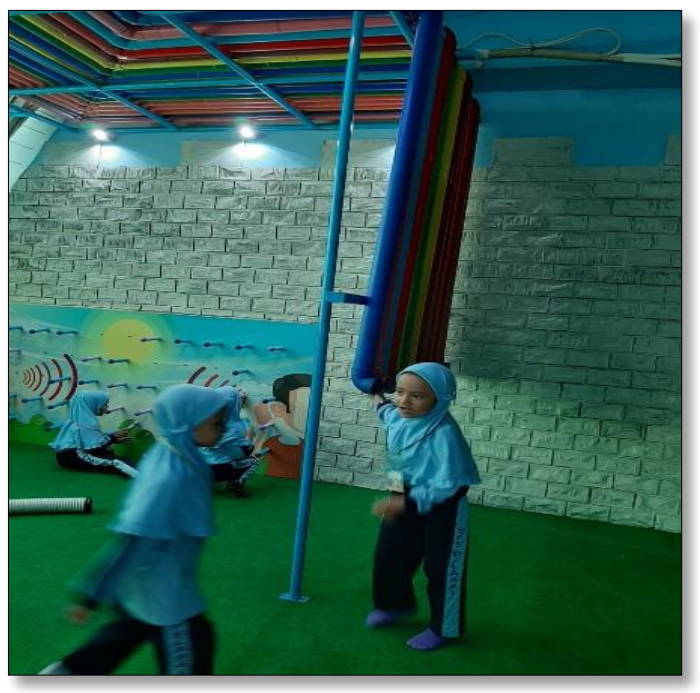

\section{Gambar 5. Salah Satu APE Telepon Pipa}

Berdasarkan beberapa penjelasan tersebut di atas menunjukkan bahwa, bentuk konsep sains, proses sains, dan bentuk aplikatif sains pada anak usia dini selama menggunakan alat permainan edukatif di PP IPTEK TMII dapat mempengaruhi pengembangan literasi sains anak usia dini. Hal ini sejalan dengan hasil penelitian Adiarti, (2009), yang menunjukkan bahwa bahan limbah dalam pembelajaran sains anak dapat diibuat menjadi alat permainan edukatif berbahan limbah dapat menumbuhkan kepekaan anak untuk selalu menjaga kebersihan dan kelestarian lingkungan sekitarnya. Hasil penelitian Anwar et al., (2013), bahwa alat permainan yang dikembangkan sebanyak 12 jenis terbukti disenangi anak untuk dimainkan, sehingga dapat mengembangkan aspek perkembangan anak di Kelompok Bermain.

Hasil penelitian Akpinar \& Aslan (2015), yang menyatakan bahwa, bermain berarti mengintegrasikan permainan, desain, dan pembelajaran secara terus menerus yang dilakukan anak dengan cara bereksperimen, menjelajah, dan melakukan uji coba. Dengan demikian, bermain merupakan salah satu metode yang efektif dalam mengembangkan literasi sains anak usia dini. Didukung hasil penelitian Pyle et al., (2018), menyatakan bahwa, mengintegrasikan kegiatan bermain di pembelajaran kelas bermain mengekspresikan sebuah kepercayaan bahwa pembelajaran dengan pendekatan bermain penting bagi perkembangan literasi anak. Melalui bermain anak akan aktif dalam mengeksplorasi pengetahuan yang terstimulasi selama berinteraksi dengan teman-temannya. Hal ini dapat dilihat dari cara anak mengkomunikasikan pengetahuannya baik secara ekspresif, represif, maupun dari tugastugas tertulis yang dibuatnya.

Rahmawati (2018), mengatakan bahwa bermain dapat memberikan kesempatan kepada seorang anak, siswa dan peserta didik bereksplorasi, menemukan, mengekspresikan perasaan, berkreasi, dan belajar secara menyenangkan. Memberikan kesempatan pada anak untuk bermain merupakan bentuk perhatian lingkungan terhadap pengembangan aspekaspek perkembangan anak. Melalui bermain ketertarikan anak dalam melakukan kegiatan belajar demi memenuhi tugas-tugas perkembangannya dapat dilakukan oleh orang tua, guru, maupun instansi-instansi terkait. Kang, Liu, dan Qu (2017) mengatakan bahwa, penggunaan strategis alat permainan sangat penting untuk menyelesaikan tugas anak. Alat permainan edukatif merupakan sarana yang dapat digunakan guru untuk menyelesaikan tugas-tugas siswa. Hasil penelitian menunjukkan bahwa, melalui srtategi yang terencana siswa ditantang untuk mengumpulkan informasi yang tertanam dalam alat yang berbeda dan mengintegrasikan informasi tersebut untuk memecahkan masalah yang kompleks meskipun 
dengan cara yang tidak terstuktur. Strategi penggunaan alat permainan edukatif yang tepat dapat merangsang ketertarikan anak dalam melakukan kegiatan belajar, sehingga mendorongnya untuk aktif dalam melakukan eksplorasi-eksplorasi di kegiatan tersebut .

\section{SIMPULAN}

Konsep sains, proses sains, dan bentuk aplikatif sains anak usia dini setelah menggunakan alat permainan edukatif di PP IPTEK TMII Jakarta dapat meningkatkan literasi sains anak usia dini. Penelitian ini menyimpulkan bahwa pengembangan literasi sains anak usia dini dapat dilakukan dengan memilih dan menggunakan alat permainan edukatif dalam bentuk konsep sains, proses sains, dan aplikatif sains. Rekomendasi penelitian yaitu mengusulkan untuk menambahkan alat permainan edukatif (APE) yang ada di PP IPTEK TMII Jakarta Timur, seperti bola gelinding, telepon pipa, musik pipa, musik dapur, bola berpacu, mesin putar, katrol, dan berjabat tangan dalam melengkapi alat permainan edukatif di taman bermainan permukiman.

\section{UCAPAN TERIMA KASIH}

Penulis mengucapkan terimakkasih kepada manajer dan pemandu di PP IPTEK TMII Jakarta Timur yang memberikan ijin dan kesempatan serta bantuan dalam penyelesaian artikel ilmiah ini.

\section{DAFTAR PUSTAKA}

Abidin, Y., \& Mulyati, T. (2017). Pembelajaran Literasi: Strategi Meningkatkan Kemampuan Literasi Matermatika, Sains, Membaca, dan Menulis. Bumi Aksara.

Adiarti, W. (2009). Alat Permainan Edukatif Berbahan Limbah Dalam Pembelajaran Sains Di Taman Kanak-Kanak. Lembaran Ilmu Kependidikan, 38(1), 78-84.

Akpinar, Y., \& Aslan, Ü. (2015). Supporting children's learning of probability through video game programming. Journal of Educational Computing Research. https://doi.org/10.1177/0735633115598492

Anwar, T, M., \& Ibrahim, H. (2013). Model Pengembangan Alat Permainan Edukatif Berbasis Sosial Budaya pada Pembelajaran Anak Didik Kelompok Bermain. Jurnal Pendidikan Dan Kebudayaan, 19(2), 236. https:/ / doi.org/10.24832/jpnk.v19i2.283

Avargil, S., Lavi R., \& D. Y. J. (2017). Students' Metacognition and Metacognitive Strategies in Science Education. Springer, 24, 33-64. https://doi.org/https://doi.org/10.1007/9783-319-66659-4_3

Ayuni, D., \& Setiawati, F. A. (2019). “Kebun Buah" Learning Media for Early Childhood Counting Ability Despa. Jurnal Obsesi : Jurnal Pendidikan Anak Usia Dini, 3(1), 1-9. https://doi.org/10.31004/obsesi.v3i1.128

Black, M. M., Walker, S. P., Fernald, L. C. H., Andersen, C. T., DiGirolamo, A. M., Lu, C., McCoy, D. C., Fink, G., Shawar, Y. R., Shiffman, J., Devercelli, A. E., Wodon, Q. T., Vargas-Barón, E., \& Grantham-McGregor, S. (2017). Early childhood development coming of age: science through the life course. In The Lancet. https://doi.org/10.1016/S0140-6736(16)31389-7

Britton, E. D., \& Schneider, S. A. (2014). Large-scale assessments in science education. In Handbook of Research on Science Education. https:/ / doi.org/10.4324/9780203097267

Gropen, J., Kook, J. F., Hoisington, C., \& Clark-Chiarelli, N. (2017). Foundations of Science Literacy: Efficacy of a Preschool Professional Development Program in Science on Classroom Instruction, Teachers' Pedagogical Content Knowledge, and Children's Observations and Predictions. Early Education and Development. https://doi.org/10.1080/10409289.2017.1279527

Hendayani, E. S. (2012). Pemanfaatan Alat Permainan Edukatif (APE) dalam Pembelajaran PAUD Seatap Margaluyu Kecamatan Cipatat Kabupaten Bandung Barat. 
EMPOWERMENT, Vol. 1, No.

Indriasih, A. (2015). Pemanfaatan alat permainan edukatif ular tangga dalam penerapan pembelajaran tematik di kelas iii sd. Pendidikan, 16(2), 127-137.

Kang, J., Liu, M., \& Qu, W. (2017). Using gameplay data to examine learning behavior patterns in a serious game. Computers in Human Behavior. https:// doi.org/10.1016/j.chb.2016.09.062

Kebudayaan, K. P. dan. (2017). Peta Jalan, Panduan, Modul dan Pedoman Pelatihan Fasilitator, Pedoman Penilaian dan Evaluasi, dan Materi Pendukung Literasi Nasional. Kementrian Pendidikan dan Kebudayaan.

Krippendorff, K. (2004). Content Analysis: An Introduction to Its Methodology. Sage Publication.

Kurniah, N., Andreswari, D., \& Kusumah, R. G. T. (2019). Achievement of Development on Early Childhood Based on National Education Standard. 295(ICETeP 2018), 351-354. https:// doi.org/10.2991/icetep-18.2019.82

McClune, B. (2017). Committing curriculum time to science literacy: The benefits from science based media resources. 25-40.

Ndeot, F., Jaya P. R. P., \& A. M. R. (2019). Praktik Pembuatan APE berbasis Budaya Manggarai di PKG Ca Nai Cibal. Jurnal Pengabdian Kepada Masyarakat, Vol. 1 (1).

Negara, I. G. N. M. K., \& Darmawati, I. D. A. A. (2017). Hubungan Antara Sosio-Demografik Dan Pengetahuan Dengan Perilaku Orang Tua Dalam Pemilihan Alat Permainan Edukatif (Ape). Jurnal Riset Kesehatan Nasional, Vol. 1, No(90), 160-163.

Pebriana, P. H. (2017). Analisis penggunaan gadget terhadap kemampuan interaksi sosial pada anak usia dini. Jurnal Obsesi: Jurnal Pendidikan Anak Usia Dini, 1(1), 1-11. https:// doi.org/10.31004/obsesi.v1i1.26

Pyle, A., Prioletta, J., \& Poliszczuk, D. (2018). The Play-Literacy Interface in Full-day Kindergarten Classrooms. Early Childhood Education Journal. https:// doi.org/10.1007/s10643-017-0852-z

Rahayuni, G. (2016). Hubungan Keterampilan Berpikir Kritis dan Literasi Sains Pada Pembelajaran IPA Terpadu Dengan Model PBM dan STM. Jurnal Penelitian Dan Pembelajaran IPA. https:/ / doi.org/10.30870/jppi.v2i2.926

Rahmawati, N. (2018). Pengembangan Alat Permainan Edukatif Dalam Pembelajaran Bahasa Arab Di Madrasah Ibtidaiyah Wahid Hasyim Sleman Yogyakarta. Journal of Arabic Learning and Teaching, 2(1), 37-44. https:// doi.org/https:// doi.org/10.15294/la.v7i1.26072

Ristikari, T., Merikukka, M., \& Hakovirta, M. (2018). The significance of timing and duration of social assistance receipt during childhood on early adult outcomes. Longitudinal and Life Course Studies. https:/ / doi.org/10.14301/1lcs.v9i3.471

Ristina, H., Linuwih, S., \& Nuswowati, M. (2019). SETS Learning Efficacy to Improve Students Science Literacy Skills. Journal of Innovative Science Education, 8(1), 427-433. https:// doi.org/10.15294/jise.v0i0.27905

Roza, D., Nurhafzah, \& Yaswinda. (2020). Urgensi Profesionalisme Guru Pendidikan Anak Usia Dini dalam Penyelenggaraan Perlindungan Anak. Jurnal Obsesi : Jurnal Pendidikan Anak Usia Dini, 4(1), 267-273. https:/ / doi.org/10.31004/obsesi.v4i1.325

Stone, C., \& Conrad, D. (2017). Preparing Today to Empower Future Learners: Preservice Teachers' Experiences Selecting \& Evaluating Children's Literature for Quality and Use in PreK-6th Grade Integrated Literacy/Science Instruction. Language and Literacy Spectrum.

Vahey P., Vidiksis R., \& A. A. (2018). Increasing Science Literacy in Early Childhood; The Connection between Home and School. American Educator.

Yamin, Y., Permanasari, A., Redjeki, S., \& Sopandi, W. (2019). Profile of students' scientific literacy in application integrated science on the theme of air pollution. Journal of Physics: Conference Series. https://doi.org/10.1088/1742-6596/1157/2/022032 